\title{
Leaf structural traits of three species of Qualea Mart. (Vochysiaceae) in a cerradão area in the Cerrado-Amazonian Forest transition
}

\author{
Atributos estruturais foliares de três espécies de Qualea Mart. (Vochysiaceae) em \\ uma área de cerradão na transição Cerrado-Floresta Amazônica
}

\section{Marcos José Gomes Pessoa ${ }^{\mathrm{I}}$ Jéssica Jeini Guisoni ${ }^{\mathrm{II}}$, Priscila Fernanda Simioni ${ }^{\mathrm{I}}$, Saulo Pireda ${ }^{\mathrm{III}}$, Vanessa Xavier ${ }^{\mathrm{IV}}$, Ivone Vieira da Silva ${ }^{\mathrm{V}}$}

\begin{abstract}
Qualea genus is commonly found in different phytophysiognomies of the Brazilian Cerrado, growing in open ecosystems to closed forest areas, under high irradiances, fires, low availability of nutrients and seasonal water deficit. We compared the leaf structural traits of Qualea grandiflora Mart., Qualea multiflora Mart., and Qualea parviflora Mart., in a cerradão area in the Cerrado-Amazonian forest transition. Leaf samples were collected at Mário Viana Municipal Biological Reserve, in Nova Xavantina, Mato Grosso state, Brasil, and processed according to the usual techniques for optical microscopy. Thick cuticle, stomatal ridges, stomata distributed between the stomatal crypts, density and distribution of tector trichomes, hypodermis, isobilateral mesophyll with few intercellular spaces, abundance of sclerenchyma associated to vascular bundles and the presence of vascular bundle sheath extensions are typical anatomic traits of xerophytic environments. We found qualitative structural differences among the species, with Qualea grandiflora having stomata with ridges distributed among stomatal crypts, and the presence of a hypodermis in Qualea multiflora, and Qualea parviflora. The results suggest that the species are xeromorphic in the region of Cerrado-Amazonian transition having leaf adaptive traits to deal with the environmental variations of their habitat.
\end{abstract}

Keywords: Xeromorphic characters; Leaf anatomy; Ecological anatomy

\section{Resumo}

Qualea é um gênero comumente encontrado em diferentes fisionomias do cerrado brasileiro, crescendo em ecossistemas abertos até áreas florestais fechadas, sujeitos à alta irradiância, incêndios, baixa disponibilidade de nutrientes e deficit hídrico sazonal. Comparam-se aqui, atributos estruturais foliares de Qualea grandiflora Mart., Qualea multiflora Mart., e Qualea parviflora Mart., em uma área de cerradão na transição entre os biomas Cerrado-Amazônia. Amostras foliares foram coletadas na Reserva Biológica Municipal Mário Viana, Nova Xavantina, Mato Grosso - Brasil, e processadas segundo as técnicas usuais para microscopia óptica. Cutícula espessa, cristas estomáticas, estômatos distribuídos entre as criptas estomáticas, densidade e distribuição dos tricomas tectores, hipoderme, mesofilo isobilateral com poucos espaços intercelulares, abundância de esclerênquima associado aos feixes vasculares e presença de extensões de bainha do feixe vascular são atributos anatômicos típicos de ambientes xerófilos. Encontraram-se diferenças estruturais qualitativas entre as espécies, com Qualea grandiflora apresentando estômatos com cristas distribuídos entre criptas estomáticas, e a presença de hipoderme em Qualea multiflora, e Qualea parviflora. Os resultados sugerem que as espécies são xeromórficas na região de transição Cerrado-Amazônia e que possuem atributos foliares adaptativos para lidar com as variações ambientais do seu habitat.

Palavras-chave: Caracteres xeromórficos; Anatomia foliar; Anatomia ecológica

\footnotetext{
Biólogo(a), Msc., Doutorando (a) em Biologia Vegetal pela Universidade do Estado do Rio de Janeiro, Rua São Francisco Xavier, No 524, PHLC, Sala 229 B, CEP 20550-013, Rio de Janeiro (RJ), Brasil. marcos-af@hotmail.com (ORCID: 0000-0001-7424-2449) / priscila-simioni@hotmail.com (ORCID: 0000-0002-1395-2866)

Bióloga, Universidade do Estado de Mato Grosso, Av. Perimetral Rogério Silva, s/n, Jardim Flamboyant, CEP 78580-000, Alta Floresta (MT), Brasil. jessicajeine@hotmail.com (ORCID: 0000-0002-8779-0126)

III Biólogo, Msc., Doutor em Biociências e Biotecnologia pela Universidade Estadual do Norte Fluminense Darcy Ribeiro, Av. Alberto Lamego, 2000 - Parque Califórnia, CEP 28013-602, Campos dos Goytacazes (RJ), Brasil. saulopireda@hotmail.com (ORCID: 0000-0002-2315-6492)

Bióloga, Mestranda em Ecologia de Recursos Naturais pela Universidade Estadual do Norte Fluminense Darcy Ribeiro, Av. Alberto Lamego, 2000 - Parque Califórnia, CEP 28013-602, Campos dos Goytacazes - (RJ), Brasil. vanessa_xbs1@hotmail.com (ORCID: 0000-0002-8054-8978)

Bióloga, Drª ., Professora Adjunto da Faculdade de Ciências Biológicas e Agrárias, Universidade do Estado de Mato Grosso, Av. Perimetral Rogério Silva, s/n, Jardim Flamboyant, CEP 78580-000, Alta Floresta (MT), Brasil. ivibot@hotmail.com (ORCID: 0000-0003-0281-0608)
} 


\section{Introduction}

Cerrado is the second largest Brazilian biome, surpassed only by Amazonian Forest, and is one of the world's biodiversity hotspots due to its high number of endemic species that are threatened by habitat loss (MITTERMEIER et al., 2005). The term Cerrado has a regional connotation in Brazil, whereas the word "savanna" is more generic and widely applied to distinct types of savanna vegetation around the world (BATALHA; MANTOVANI, 2000). The Cerrado biome possesses forest, savanna and grassland formations (RIBEIRO; WALTER, 2008). Savanna formations constitute almost half of the Cerrado region (SILVA et al., 2006). Among the forest, savanna and grassland formations of Cerrado it is possible to find transitional vegetation subjected to different edaphic, climatic and pedological conditions (MARIMON-JUNIOR; HARIDASAN, 2005; RIBEIRO; WALTER, 2008), conferring to the biome recognition as the richest savanna in the world (MITTERMEIER et al., 2005).

Cerradão is a forest formation of Brazilian Cerrado with sclerophyllous characteristics (RIBEIRO; WALTER, 2008). Occurs in both dystrophic and mesotrophic soils (MARIMONJUNIOR; HARIDASAN, 2005) and its plants are subjected to different environmental conditions, such as seasonal fires, well-weathered soils with low nutrients availability and variation in the solar radiation (REATTO et al., 2008).

Morpho-anatomical characteristics of plants are strongly influenced by environmental factors, particularly those associated with irradiance, amount of rainfall, soil type and elevation (FERREIRA et al., 2015). These factors vary in space and time and may act as conditioning factors for the establishment and growth of different plant species (FAHN, 1986). Leaves are the most exposed plant organs to these environmental conditions, and their modifications have been interpreted as adaptive responses to environmental changes (FAHN, 1986). Anatomical studies have revealed a great amount of variation in leaf structure of woody Cerrado species (ARIANO; SILVA, 2016; SIMIONI et al., 2017), mainly as a response to variation in light intensity, soil nutrient content and seasonal effects (JUSTO et al., 2005), which can, consequently, affect water use efficiency and carbon fixation (ROSSATO; HOFFMANN; FRANCO, 2009).

We have considered that comparative studies have been increasingly used to diagnose how plants would respond to changes in the environmental conditions of their original habitat, and the possible adaptive strategies and the lack of anatomical and ecological studies for plant species in the region of transition between Cerrado and Amazonian Forest. Thus, this study aimed to compare the leaf structural traits of Qualea grandiflora, Qualea multiflora, and Qualea parviflora, in order to identify characteristics that confer to these species adaptive advantages in a Cerradão area in the transition between Cerrado and Amazonian biomes.

\section{Material and methods}

Leaf samples were collected in an area of Cerradão located at Reserva Biológica Municipal Mário Viana, in the municipality of Nova Xavantina $\left(14^{\circ} 41^{\prime} \mathrm{S}, 52^{\circ} 20^{\prime} \mathrm{W}\right)$, in the eastern Mato Grosso state, a transition area between the Cerrado and Amazonian Forest biomes (MARIMONJUNIOR; HARIDASAN, 2005). The area is a conservation unit of approximately 500 ha, has an average elevation of $340 \mathrm{~m}$, and is characterized by savanna and forest physiognomies typical of Cerrado and pre-Amazonian Forest formations (MARIMON et al., 2006).

The terrain is flat to softly-undulating. The soils of the region are classified as RedYellow Latosol and Yellow Latosol, predominantly dystrophic, alic, deep and well drained with a medium texture (REATTO et al., 2005). The soils in the study area have $\mathrm{pH}<5$, low levels of calcium and magnesium, and high levels of exchangeable aluminum (MARIMON-JÚNIOR; HARIDASAN, 2005). The climate is Aw, with an average annual rainfall of $1.600 \mathrm{~mm}$ and an average annual temperature of $24.4^{\circ} \mathrm{C}$, with two distinct seasons: a cold dry season from April to September, and a warm and rainy season from October to March (ALVARES et al., 2013). 
The study species, Qualea grandiflora, Qualea multiflora and Qualea parviflora, are part of the woody component of the Cerrado phytophysiognomy in Reserva Biológica Municipal Mário Viana (MARIMON-JÚNIOR; HARIDASAN, 2005). Five individuals of each species were selected arbitrarily. Leaf samples, collected from branches which leaves were fully expanded, were fixed in FAA50 in the field for 48 hours and later stored in 70\% ethanol (JOHANSEN, 1940).

Anatomical study of cross-sections of the middle region of the leaves, obtained by freehand, was performed using a trinocular microscope (Leica ICC50). The sections were stained with Astra Blue and Basic Fuchsin and placed on semi-permanent slides (JOHANSEN, 1940). Subsequent data analysis was performed using Leica Application Suite Version 1.7.0 software.

The images obtained illustrate the general anatomical patterns of the studied species, with emphasis on structural characters, used to analytically describe the species, and the possible adaptive strategies.

\section{Results and discussion}

Leaves of the three species have a thick cuticle covering the adaxial surface (Figures 1A, 1B and 1C), while in Qualea parviflora this thickening is also observed on the abaxial surface (Figure 1C). The thick cuticle may be a strategy related to the restriction of water loss. The cuticle is composed of cutin, a lipophilic substance which acts as a barrier to the diffusion of water and solutes (SCHREIBER, 2005). Thus, in xeric environments, a thick cuticle can be considered a strategy for limiting water loss, which seems to explain the presence of this characteristic in the studied species.

The epidermis is uni-seriate on both surfaces of the studied species (Figures 1A, 1B and 1C). In Qualea grandiflora, the epidermal cells are voluminous, with anticlinal and elongated walls, decreasing in volume and height at the midrib of the adaxial surface (Figures $1 \mathrm{~A}$ and $2 \mathrm{~A}$ ). In contrast, the cells of the abaxial surface are smaller and rectangular, and possess stomatal crypts with numerous unicellular trichomes (Figure 1A). In Qualea multiflora, the adaxial epidermal cells are rectangular and of varying lengths along the epidermis, while the abaxial epidermal cells are rectangular and smaller (Figure 1B). Small rounded epidermal cells are present on both surfaces of Qualea parviflora, but are smaller adaxially (Figure 1C).

The presence of tector trichomes on leaves of species occurring in xeric environments is another characteristic that may contribute to the restriction of water loss (SIMIONI et al., 2017). Santos et al. (2016) demonstrated that the presence of tector trichomes on leaf surfaces create a humid microclimate, resulting in reduced water loss from evapotranspiration, and reflect solar radiation, thus avoiding leaf heating. In addition to these benefits, trichomes can also protect leaves against herbivory (SATO; KUDOH, 2017) since they act as the first line of defense against attack by phytophagous insects (KARIYAT et al., 2017).

The three species have hypostomatic leaves (Figures 1A, 1B and 1C), in which the stomata are located at the same level or slightly above the other epidermal cells (Figures 1A, 1B and 1C), while ridges forming a suprastomatal chamber are found only in Qualea grandiflora (Figure 1A). The predominance of hypostomatic leaves among plants in xeric environments suggests that they may also be a strategy for restricting water loss through evapotranspiration. The location of stomata on the abaxial surface of leaves reduces their exposure to high irradiance rates and low air humidity, thus reducing the loss of water to the environment (EVERT, 2006). In addition, the level at which the stomata are positioned in relation to other epidermal cells is also considered to be related to environmental conditions (ALQUINI et al., 2006). The presence of stomata in stomatal crypts is a common strategy of plants in xeric environments since these crypts facilitate a more humid internal microclimate, which avoids water loss through evapotranspiration during stomatal opening (ALQUINI et al., 2006; DIAS, 2008).

A hypodermis is present below the epidermis of Qualea multiflora and Qualea parviflora (Figures 1B and 1C). In Qualea multiflora, the hypodermis consists of only a single layer, while 
in Qualea parviflora there are two ones (Figure 1B and 1C).

The mesophyll is isobilateral in the three studied species (Figures. 1A, 1B and 1C). In Qualea grandiflora it consists of three to four layers of palisade parenchyma (Figure 1A), as it is in Qualea multiflora (Figure 1B), whereas in Qualea parviflora the mesophyll is composed of five layers of palisade parenchyma (Figure 1C). In all three species, the vascular bundles of the leaf blade are collateral and organized in a single series with larger and smaller bundles alternating (Figure 1A). These bundles are involved by a sclerenchymatous sheath, which extends to the epidermis in Qualea grandiflora (Figure 1A) and to the hypodermis in Qualea multiflora and Qualea parviflora (Figure 1B).

The sclerenchyma fibers associated with vascular bundles are an important feature of xerophytic plants (LIESCHE; MARTENS; SCHULZ, 2011) and are responsible for providing structural support to tissue, thus preventing its collapse (SCATENA; SCREMIN-DIAS, 2006). Moreover, these fibers contribute to water retention by preventing its passage via apoplastic routes and, consequently, provide plants with greater resistance to wilting (ROSADO; MATTOS, 2007).

The structure of leaves with thicker palisade parenchyma, or parenchyma composed of several layers of cells, may be related to environments with high irradiance (RABELO et al., 2013). In such conditions these tissues act by distributing the irradiance equally over the mesophyll of the leaf, therefore maximizing light uptake by the chloroplasts (VOLGEMANN; MARTIN, 1993). Additionally, tissue thickening may increase the number of chloroplasts located near cell walls, which facilitates the arrival of $\mathrm{CO} 2$ in the chloroplast stroma, thus favoring greater $\mathrm{CO} 2$ fixation (OGUCHI; HIKOSAKA; HIROSE, 2005). This characteristic is a strategy that can contribute to the maintenance of photosynthetic performance in conditions with high irradiance rates.

Figure 1 - Cross sections of the mesophyll of Qualea grandiflora (A), Qualea multiflora (B) and Qualea parviflora $(\mathrm{C})$. Abbreviations: sclerenchymatous sheath $(\mathrm{Be})$, stomatal crypts $(\mathrm{Cpt})$, hypodermis $(\mathrm{Hp})$, palisadic parenchyma cells $(\mathbf{p p})$, Cuticle $(\rightarrow)$, ridges $(\neg)$. Scale

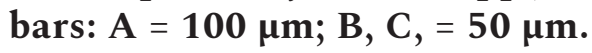

Figura 1 - Seções transversais do mesofilo de Qualea grandiflora (A), Qualea multiflora (B) e Qualea parviflora (C). Abreviaturas: Bainha esclerenquimática (Be), Criptas estomáticas $(\mathrm{Cpt})$, Hipoderme (Hp), Paliçada de células do parênquima (pp), Cutícula $(\rightarrow)$, Cristas $(\Rightarrow)$.

Escala das barras: $\mathrm{A}=100 \mu \mathrm{m} ; \mathrm{B}, \mathrm{C},=50 \mu \mathrm{m}$.

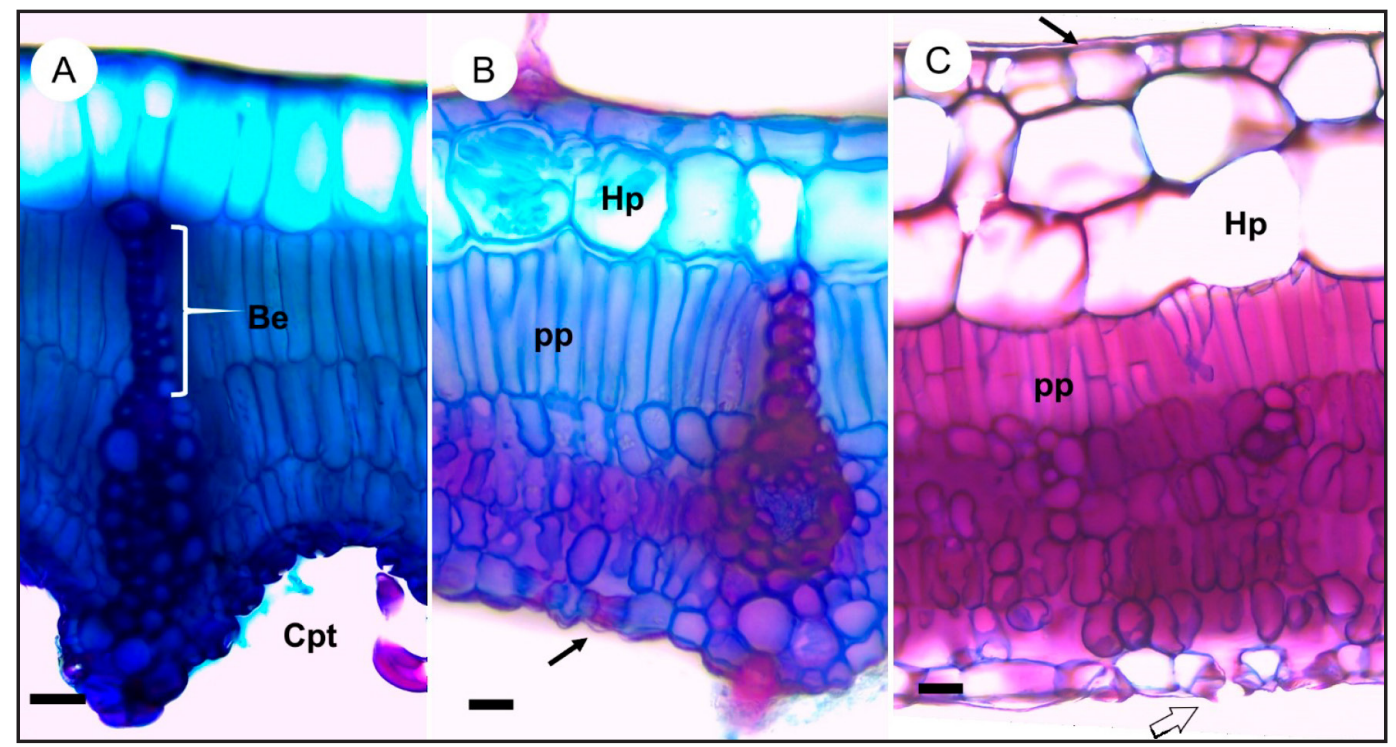

Source: Pessoa et al. (2019)

Fonte: Pessoa et al. (2019) 
Figure 2 - Cross sections of the general aspects and midrib of Qualea grandiflora (A, B, C, D and E), Qualea multiflora (F, G, H and I) and Qualea parviflora (J, K, L, M and N). Abbreviations: Epidermis (Ep), collenchyma (Col), sclerenchyma fibers $(\mathrm{Fe})$, air space $(\mathrm{La})$, tector trichomes (Tt). Scale bars: A, B, F, J, K, N = $100 \mu \mathrm{m} ; \mathrm{C}, \mathrm{D}, \mathrm{E}, \mathrm{G}, \mathrm{H}, \mathrm{I}, \mathrm{L}, \mathrm{M}=\mathbf{5 0} \mu \mathrm{m}$.

Figura 2 - Seções transversais dos aspectos gerais e da nervura central de Qualea grandifolia (A, B, C, D e E), Qualea multiflora (F, G, H e I) e Qualea parviflora (J, K, L, M e N). Abreviaturas: Epiderme (Ep), Colênquima (Col), Fibras esclerenquimáticas ( $\mathrm{Fe})$. Lacunas de ar (La), Tricomas tectores (Tt). Escala das barras: A, B, F, J, K, N = $100 \mu \mathrm{m}$; C, D, E, G, H, I, L, M = $50 \mu \mathrm{m}$.

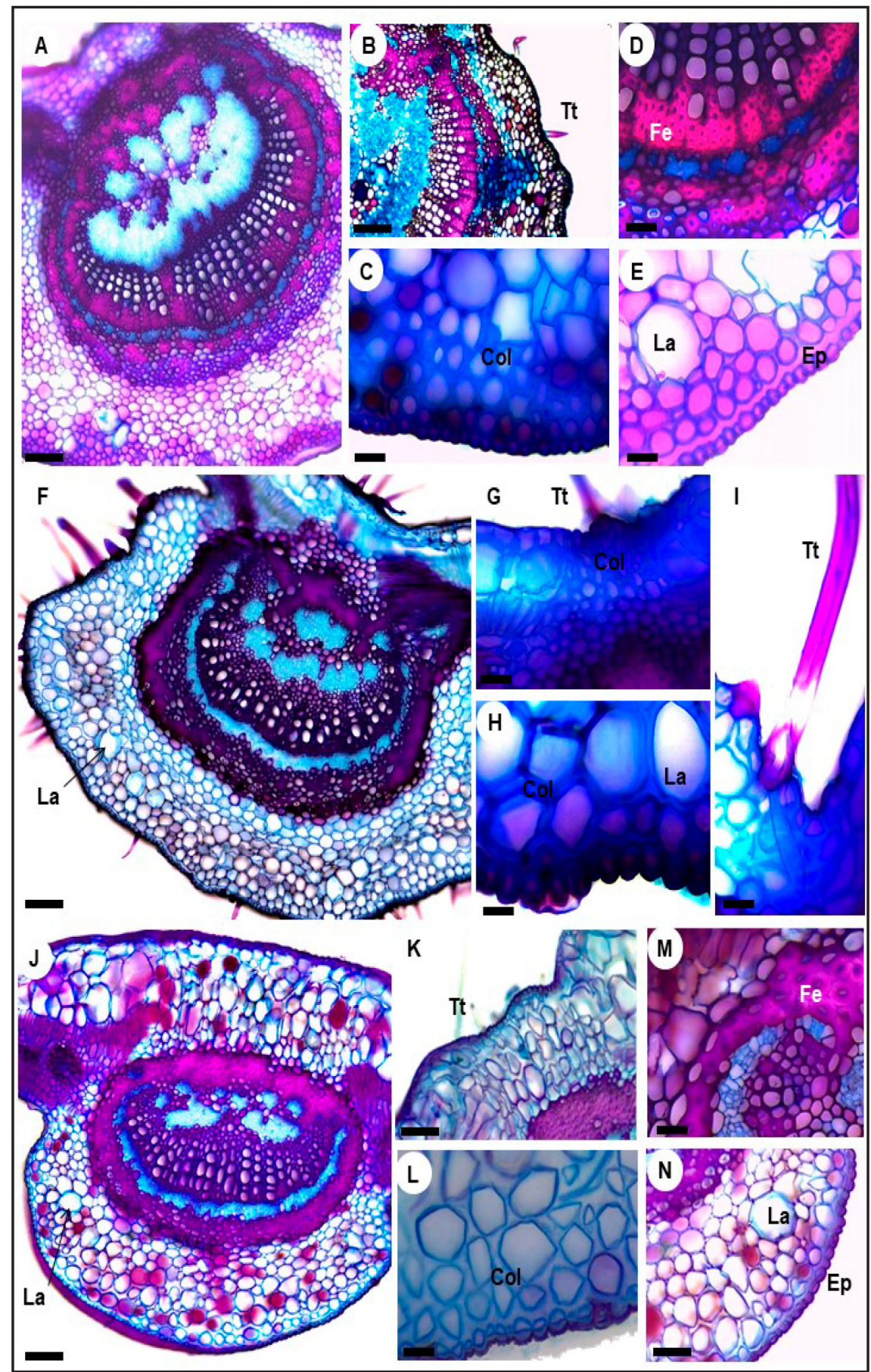

Source: Pessoa et al. (2019)

Fonte: Pessoa et al. (2019) 
The midribs of the studied species possess bicolateral bundles arranged in a closed arch with extensive sclerenchyma fibers and filled with parenchyma (Figures 2A, 2F and 2J). The midribs have a biconvex shape with the presence of lamellar collenchyma below the epidermis on both surfaces of Qualea grandifolia and Qualea multiflora (Figures 2C and 2H) and lacunar collenchyma in Qualea parviflora (Figures $2 \mathrm{~K}$ and $2 \mathrm{~L}$ ). In all three species, the fundamental parenchyma predominantly faces the abaxial surface and contains air spaces (Figures $2 \mathrm{E}, 2 \mathrm{H}$ and $2 \mathrm{~N}$ ).

Unicellular trichomes are present in the three studied species, however, their distribution on the midrib varies (Figures 2B, 2F, 2G, 2I and 2K). In Qualea grandiflora, trichomes are rare on the adaxial epidermis (Figure 2B), whereas in Qualea multiflora they are on both surfaces, but more frequent on the abaxial surface (Figure 2F, 2G and 2I). In Qualea parviflora (Figure 2K), trichomes are present on both surfaces, although in a lower frequency than Qualea multiflora.

The anatomical description of the leaf blades of the three studied species shows a consistent pattern of anatomical characters that are typical of xerophytic plants subject to elevated temperature, high irradiance, low relative humidity and seasonal water deficit, the predominant conditions of Brazilian Cerrado ecosystems. These anatomical characters are: the presence of air spaces; a thick cuticle on the adaxial surface; stomata with stomatal ridges and distributed between stomatal crypts; density and distribution of tector trichomes on the leaf blade; presence of a hypodermis; isobilateral mesophyll with few intercellular spaces; abundant sclerenchyma and sclerenchyma associated with vascular bundles; and the presence of sheath extensions around vascular bundles.

These characters are widely considered to be xeromorphic (FERREIRA et al., 2015; ARIANO; SILVA, 2016; SIMIONI et al., 2017), and were discussed in this work from the ecological point of view. For example, the air spaces found in the midrib of these species of Qualea may be a strategy to facilitate water transport by capillarity from the roots to the leaves (MEYER, 1940), consequently reflecting a strategic mechanism for water economy (SCATENA; SEGECIN, 2005).

\section{Conclusions}

Thick cuticle, stomatal ridges, stomata distributed between the stomatal crypts, density and distribution of tector trichomes, hypodermis, isobilateral mesophyll with few intercellular spaces, abundance of sclerenchyma associated to vascular bundles and presence of vascular bundle sheath extensions are leaf anatomical traits which indicate the species studied are xeromorphic in the region of Cerrado-Amazon transition, thus, adapted to the environmental variations of their habitat. In conclusion, we found qualitative structural differences between the studied species. Qualea grandiflora presents stomata with ridges distributed among stomatal crypts, Qualea multiflora has the presence of a hypodermis as well as found in Qualea parviflora, whereas this last one differs from the other two in number of layers of palisade parenchyma.

\section{Acknowledgments}

The authors acknowledge financial support from Conselho Nacional de Desenvolvimento Científico e Tecnológico (CNPq), Fundação de Amparo à Pesquisa do Rio de Janeiro (FAPERJ), and Universidade do Estado do Mato Grosso - UNEMAT.

\section{References}

ALQUINI, Y. et al. Epiderme. In: APPEZZATO-DA-GLÓRIA B. et al. Anatomia vegetal. 2. ed. Viçosa, MG: UFV, 2006. p. 78- 99. 
ALVARES, C. A. et al. Koppen's climate classification map for Brazil. Meteorologische Zeitschrift, Berlin, v. 22, n. 6, p. 711-728, dec. 2013.

ARIANO, A. P. R.; SILVA, I. V. Leaf anatomy of Qualea parviflora (Vochysiaceae) in three phytophysiognomies of the Mato Grosso State, Brazil. Acta Amazonica, Manaus, v. 45, n. 2, p. 337-346, jun. 2016.

BATALHA, M. A.; MANTOVANI, W. Reproductive phenological patterns of cerrado plant species at the Pé-de-Gigante Reserve (Santa Rita do Passa Quatro, SP, Brazil): a comparison between the herbaceous and woody floras. Revista Brasileira de Biologia, São Carlos, v. 60, n. 1, p. $129-145$, fev. 2000 .

DIAS, L. B. Águas nas plantas. [S. 1.]: UFLA; CEAP design, 2008.

EVERT, R. F. Esau's Plant anatomy: meristems, cells, and tissues of the plant body: their structure, function, and development. 3rd ed. [S. 1.]: Wiley-Interscience, 2006.

FAHN, A. Structural and functional properties of trichomes of xeromorphic leaves. Annals of Botany, London, v. 57, p. 631-637, 1986.

FERREIRA, C. S. et al. Anatomia da lâmina foliar de onze espécies lenhosas dominantes nas savanas de Roraima. Acta Amazonica, Manaus, v. 45, n. 4, p. 337-346, 2015.

JOHANSEN, D. A. Plant Microtechnique. New York: McGraw-Hill, 1940. 523 p.

JUSTO, C. F. et al. Leaf anatomical plasticity of Xylopia brasiliensis Sprengle (Annonaceae). Acta Botanica Brasilica, São Paulo, v. 19, n. 1, p. 111-123, 2005.

KARIYAT, R. R. et al. Non-glandular trichomes of Solanum carolinense deter feeding by Manduca sexta caterpillars and cause damage to the gut peritrophic matrix. Proceedings of the Royal Society B, [s. 1.], v. 284, n. 1849, 2017. DOI: 10.1098/rspb.2016.2323, 2017.

LIESCHE, J.; MARTENS, H. J.; SCHULZ, A. Symplasmic transport and phloem loading in gymnosperm leaves. Protoplasma, Wien, v. 248, n. 1, p. 181-190, 2011.

MARIMON, B. S. et al. Observations on the vegetation of northeastern Mato Grosso, Brazil. IV. An analysis of the Cerrado-Amazonian Forest ecotone. Edinburgh Journal of Botany, Edinburgh, v. 63, n. 2-3, p. 23-341, nov. 2006.

MARIMON-JUNIOR, B. H.; HARIDASAN, M. Comparação da vegetação arbórea e características edáficas de um cerradão e um cerrado sensu stricto em áreas adjacentes sobre solo distrófico no leste de Mato Grosso, Brasil. Acta Botanica Brasilica, São Paulo, v. 19, n. 4, p. 913-926, jun. 2005.

MEYER L. Zur anatomie und entwicklungsgeschichte der Bromeliaceenwurzein. Planta, [s. 1.], v. 31, n.3. p. 492-522, december. 1940.

MITTERMEIER, R. A. et al. A brief history of biodiversity conservation in Brazil. Conservation Biology, Boston, v. 19, n. 3, p. 601-611, jun. 2005.

OGUCHI, R.; HIKOSAKA, K.; HIROSE, T. Leaf anatomy as a constraint for photosynthetic acclimation: differential responses in leaf anatomy to increasing growth irradiance among three deciduous trees. Plant, Cell \& Environment, Oxford, v. 28, p. 916-927, 2005.

RABELO, G. R. et al. Structural and ecophysiological adaptations to forest gaps. Trees, Santa Monica, v. 27, p. 259-272, nov. 2013.

REATTO, A. et al. Solos do bioma Cerrado: aspectos pedológicos. In: SANO, S. M.; ALMEIDA, S. P.; RIBEIRO, J. F. (ed.). Cerrado: ecologia e flora. Brasília: EMBRAPA, 2008. v. 1, p. 107-150.

RIBEIRO, J. F.; WALTER, B. M. T. As principais fitofisionomias do Bioma Cerrado. In: SANO, S. M.; ALMEIDA, S. P.; RIBEIRO, J. F. (ed.). Cerrado: ecologia e flora. Brasília: EMBRAPA, 2008. 
v. 1, p. 151-212.

ROSADO, B. H. P.; MATTOS, E. A. Variação temporal de características morfológicas de folhas em dez espécies do Parque Nacional da Restinga de Jurubatiba, Macaé, RJ, Brasil. Acta Botanica Brasilica, São Paulo, v. 21, p. 741-752, 2007.

ROSSATO, D. R.; HOFFMANN, W. A.; FRANCO, C. A. Características estomáticas de pares congenéricos de cerrado e mata de galeria crescendo numa região de transição no Brasil Central. Acta Botanica Brasilica, São Paulo, v. 23, n. 1, p. 499-508, 2009.

SANTOS, M. S. et al. Effects of water deficit on morphophysiology, productivity and chemical composition of Ocimum africanum Lour (Lamiaceae). African Journal of Agricultural Research, [s. 1.], v. 11, n. 21, p. 1924-1934, may 2016.

SATO, Y.; KUDOH, H. Fine-scale frequency differentiation along a herbivory gradient in the trichome dimorphism of a wild Arabidopsis. Ecology and Evolution, [s. l.], v. 7, n. 7, p. 2133-2141, apr. 2017.

SCATENA, V. L.; SCREMIN-DIAS, E. Parênquima, colênquima e esclerênquima. In: APPEZZATO-DA-GLÓRIA B. et al. Anatomia vegetal. 2. ed. Viçosa, MG: UFV, 2006. p. 109-127.

SCATENA V. L.; SEGECIN S. Anatomia de Tillandsia L. (Bromeliaceae) dos Campos Gerais, Paraná, Brasil. Revisa Brasileira de Botânica, São Paulo, v. 28, n. 3, p. 635-349, sept. 2005.

SCHREIBER, L. Polar paths of diffusion across plant cuticles: new evidence for an old hypothesis. Annals of Botany, London, v. 95, n. 7, p. 1069-1073, 2005.

SILVA, J. F. et al. Spatial heterogeneity, land use and conservation in the cerrado region of Brazil. Journal of Biogeography, Oxford, v. 33, p. 536-548, 2006.

SIMIONI, P. F. et al. Elucidating adaptive strategies from leaf anatomy: do Amazonian savannas present xeromorphic characteristics? Flora, London, v. 226, p. 38-46, 2017.

VOGELMANN, T. C.; MARTIN, G. The functional significance of palisade tissue: penetration of directional versus diffuse light. Plant Cell \& Environment, Oxford, v. 16, p. 65-72, jan. 1993. 